\title{
Two new species and several new records of the millipede genus Epanerchodus Attems, 1901 from China (Diplopoda: Polydesmida: Polydesmidae)
}

\section{Ава новых вида и несколыко новых находок двупарноногих многоножек рода Epanerchodus Attems, 1901 из Китая (Diplopoda: Polydesmida: Polydesmidae)}

\author{
Sergei I. Golovatch \\ Сергей И. Головач
}

Institute for Problems of Ecology and Evolution, Russian Academy of Sciences, Leninsky prospekt 33, Moscow 119071 Russia. E-mail: sgolovatch@yandex.ru

Институт проблем экологии и эволюции РАН, Ленинский проспект, 33, Москва 119071 Россия.

KEY WORDS: millipedes, taxonomy, iconography, new species, mainland China.

КЛЮЧЕВЫЕ СЛОВА: двупарноногие многоножки, таксономия, иконография, новый вид, материковый Китай.

ABSTRACT. Two new species of Epanerchodus are described from southwestern China: E. liuae sp.n. from Yunnan, and E. wolongensis sp.n. from Sichuan. New records of E. potanini Golovatch, 1991 and $E$. martensi Golovatch, 2014 are also presented.

How to cite this paper: Golovatch S.I. 2021. Two new species and several new records of the millipede genus Epanerchodus Attems, 1901 from China (Diplopoda: Polydesmida: Polydesmidae) // Arthropoda Selecta. Vol.30. No.2. P.143-152. doi: 10.15298/ arthsel.30.2.01

РЕЗЮМЕ. Описаны два новых вида рода Epanerchodus из Юго-Западного Китая: E. liuae sp.n. из Юннани и E. wolongensis sp.n. из Сычуаня. Представлены новые находки видов E. potanini Golovatch, 1991 и E. martensi Golovatch, 2014.

\section{Introduction}

The millipede fauna of continental China is very rich and diverse, presently encompassing $340+$ species from 71 genera, 26 families and 11 orders [Golovatch, Liu, 2020]. Epanerchodus Attems, 1901 is one the most species-rich genera of the family Polydesmidae, and the largest in Asia, ranging from Central Asia in the west, through the Himalayas, to the Russian Far East, Korea, Japan and Taiwan in the east. At the moment, this eastern Palaearctic diplopod genus contains 120 accepted species, both epigean and cavernicolous, including 27 species, mostly keyed and mapped, in mainland China alone [Liu, Golovatch, 2018; Liu, Huo, 2020].

The present paper puts on record another small collection of Epanerchodus from China. This material comprises two new species and a number of new records, all epigean, of two already known congeners.

\section{Material and methods}

The samples underlying this contribution were either donated to me for treatment by Igor Belousov, Ilya Kabak and Genrikh Davidian (all St. Peterburg, Russia), housed in the Zoological Museum of the State University of Moscow (ZMUM), Russia, or handed to me on loan by Jochen Martens (Mainz, Germany) and Peter Jäger (Senckenberg Museum, Frankfurt am Main (SMF), Germany), to be deposited in the SMF.

The pictures were taken with a Canon EOS 5D digital camera and stacked using Zerene Stacker software. Final image processing was performed with Adobe Photoshop $\mathrm{CC}$. The line drawings were made by the author.

\section{Taxonomy}

\section{Epanerchodus luiae sp.n.}

Figs 1-12.

HOLOTYPE $\sigma^{7}$ (ZMUM), China, Yunnan Prov., SSW of Lan-

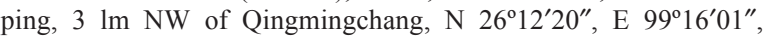
$2480 \mathrm{~m}$ a.s.1., 28.V.2018, I. Belousov \& I. Kabak leg.

NAME. Honours Mrs Dr. Liu Weixin, a prominent specialist in millipede taxonomy in China.

DIAGNOSIS. Differs from congeners by the rather large size (width $>4.0 \mathrm{~mm}$ ), coupled with the head being narrower than the collum, the absence of sphaerotrichomes, lateral bulges on $\sigma^{7}$ prefemora, and an exomere, and the shapes of the endomere (en) and its basal processes $\mathbf{p 1}$ and p2. See also Remarks below.

DESCRIPTION. Length ca $25 \mathrm{~mm}$, width of midbody pro- and metazonae 2.0 and $4.2 \mathrm{~mm}$, respectively $\left(\sigma^{7}\right)$. Colouration in alcohol rather uniformly brown with lighter 

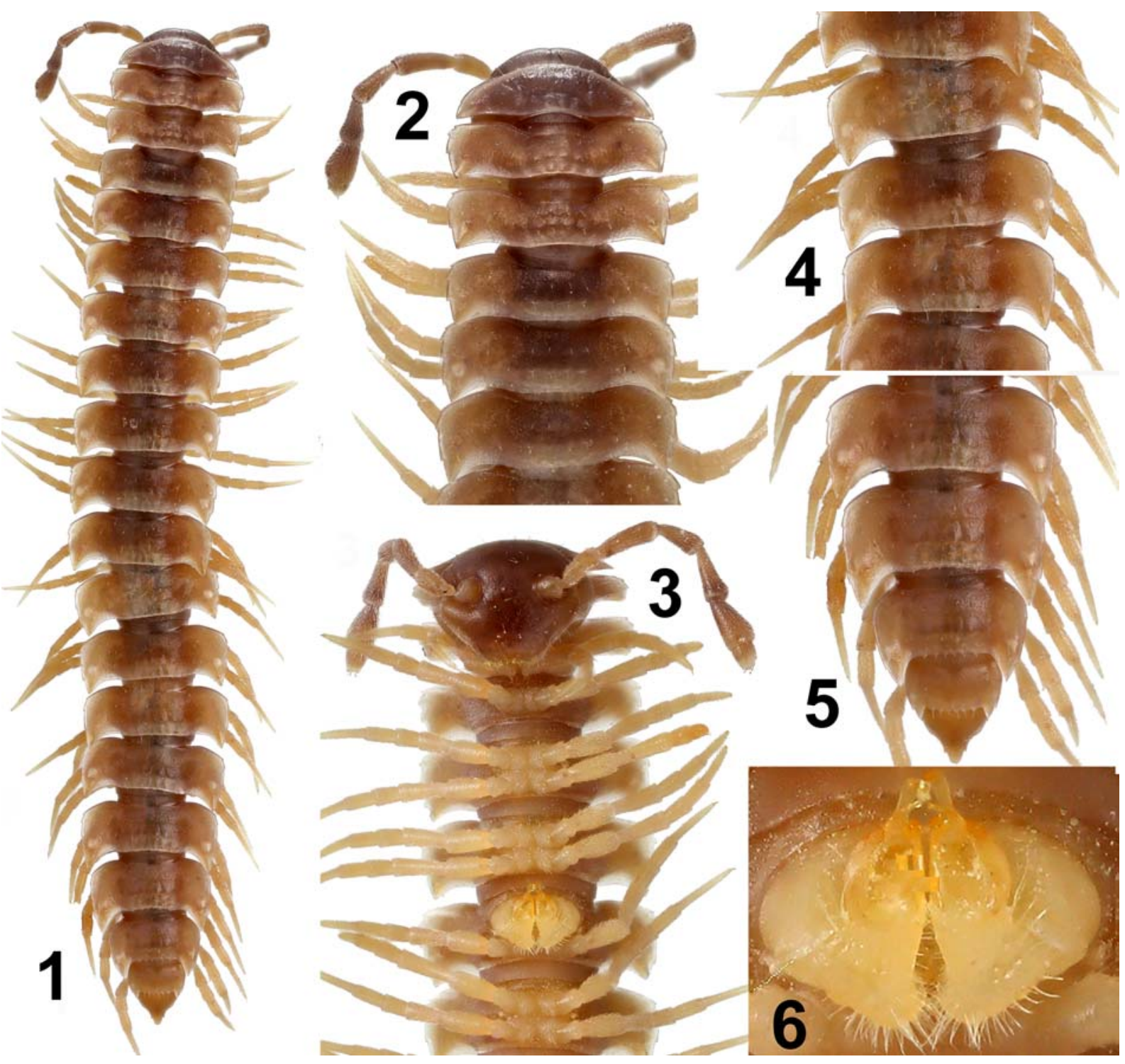

Figs 1-6. Epanerchodus luiae sp.n., holotype. 1 - habitus, dorsal view; 2, 3 - anterior part of body, dorsal and ventral views, respectively; 4 - midbody segments, dorsal view; 5 - posterior part of body, dorsal view; 6 - gonopods in situ, ventral view. Pictures by K.V. Makarov, taken not to scale.

Рис. 1-6. Epanerchodus luiae sp.n., голотип. 1 - общий вид, сверху; 2, 3 - передняя часть тела, соответственно сверху и снизу; 4 - среднетуловищные сегменты, сверху; 5 - задняя часть тела, сверху; 6 - гоноподы на месте, снизу. Фотографии К.В. Макарова, снято без масштаба.

brown paraterga and legs (Figs 1-5). Body with 20 segments. Tegument moderately shining, texture very delicately shagreened. Head pilose nearly throughout, with squarish genae. Antennae long and only slightly clavate due to highest antennomere 6 (height measured from the lower to the higher edge) (Figs 1-3), either reaching past segment 3 dorsally $\left(\sigma^{7}\right)$; antennomere 3 the longest, ca $1.3 x$ longer than subequal antennomeres $4-6 ; 5^{\text {th }}$ and $6^{\text {th }}$ each with a small, compact, distodorsal group of bacilliform sensilla; antennomere 7 with a minute dorsoparabasal cone and a distodorsal group of microscopic sensilla.

In width, head $<$ collum $<$ segment $3=4<2<5=15$, thereafter body gradually tapering towards telson (Fig. 1). Paraterga strongly developed, set high (at about upper $1 / 4$ of midbody height), starting with collum, dorsum very faintly convex; paraterga mostly weakly upturned above dorsum. Caudolateral corner of paraterga spiniform, postcollum ones extending increasingly past rear tergal margin, especially clearly so in segments $16-18$. All poreless segments with three, all pore-bearing ones with four, minute incisions at lateral margin. Front margins of metaterga narrowly bordered and forming distinct shoulders. Pore formula normal, ozopores evident, dorsal, located in front of posteriormost marginal indentation. Metatergal sculpture typical, poorlydeveloped, obliterate, with three transverse rows of typical (= polydesmid), setigerous, polygonal bosses (Figs 1, 2, 4, 8). Tergal setae very short, slightly longer only on collum, simple, often obliterate. Stricture between pro- and metazo- 


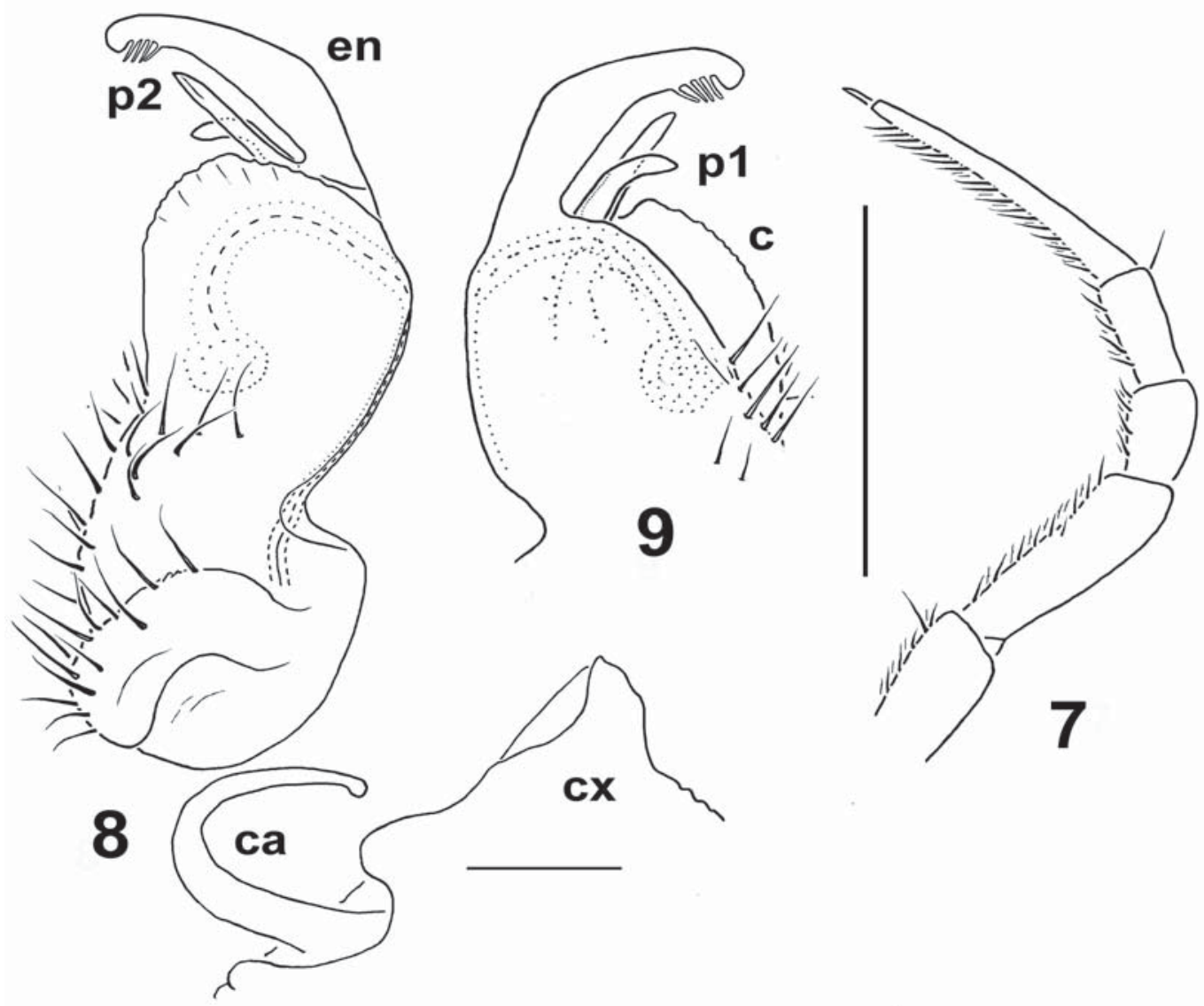

Figs 7-9. Epanerchodus luiae sp.n., holotype. 7 - leg 9, lateral view; 8, 9- left gonopod, mesal and lateral views, respectively. Scale bars: $0.5(7)$ and $0.1 \mathrm{~mm}(8,9)$. Designations explained in text.

Рис. 7-9. Epanerchodus luiae sp.n., holotype. 7 - нога 9, сбоку; 8, 9 - левый гонопод, соответственно изнутри и сбоку. Масштаб: 0,5 (7) и 0,1 мм $(8,9)$. Объяснения обозначений в тексте.

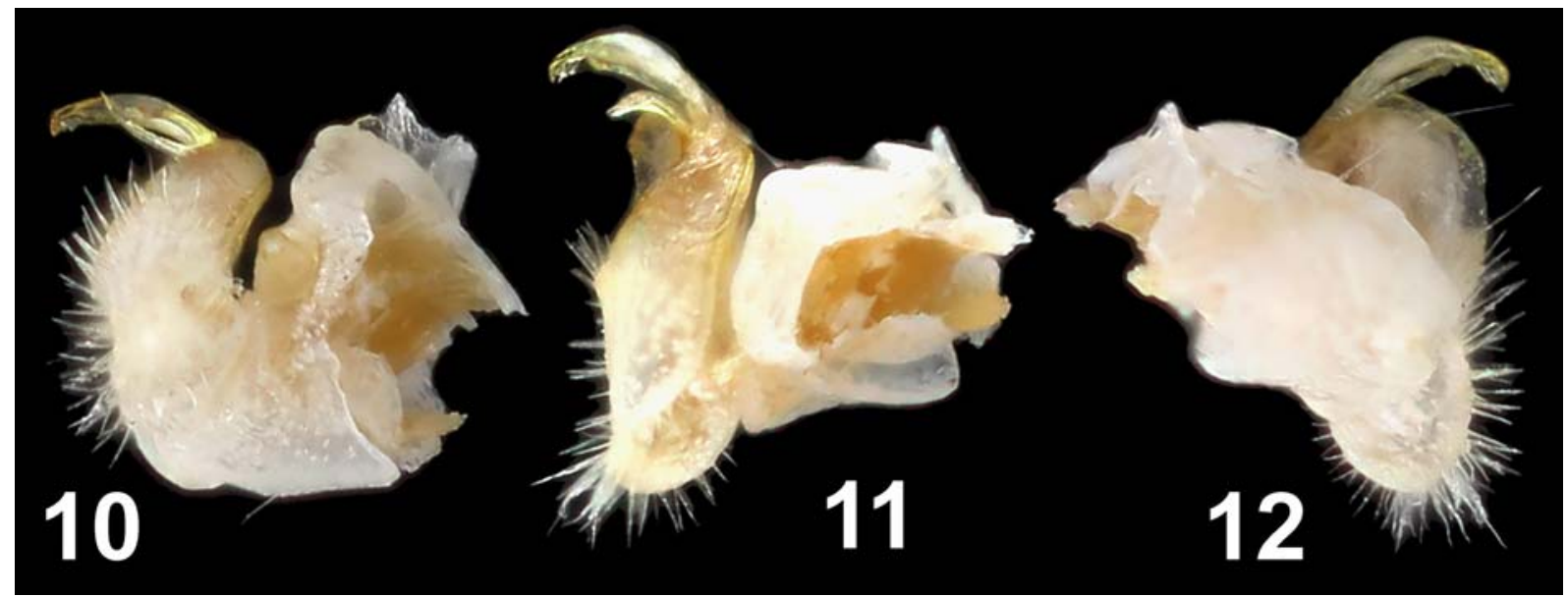

Figs 10-12. Epanerchodus luiae sp.n., holotype, right gonopod, ventromesal, mesal and ventrolateral views, respectively. Pictures by K.V. Makarov, taken not to scale.

Рис. 10-12. Epanerchodus luiae sp.n., голотип, правый гонопод, соответственно одновременно изнутри и снизу, изнутри и одновременно сбоку и снизу. Фотографии К.В. Макарова, снято без масштаба.

na wide, shallow and nearly smooth. Limbus very thin, microdenticulate. Pleurosternal carinae absent. Epiproct rather short, conical, pre-apical lateral papillae evident (Fig. 5). Hypoproct semi-circular; caudal, paramedian, setigerous pa- pillae small and well-separated. Sterna without modifications, densely setose. Legs $\left(\sigma^{7}\right)$ generally rather long and slender, apparently slightly incrassate (Figs $1-5,7$ ), ca 1.71.8 times as long as midbody height, densely setose, almost 


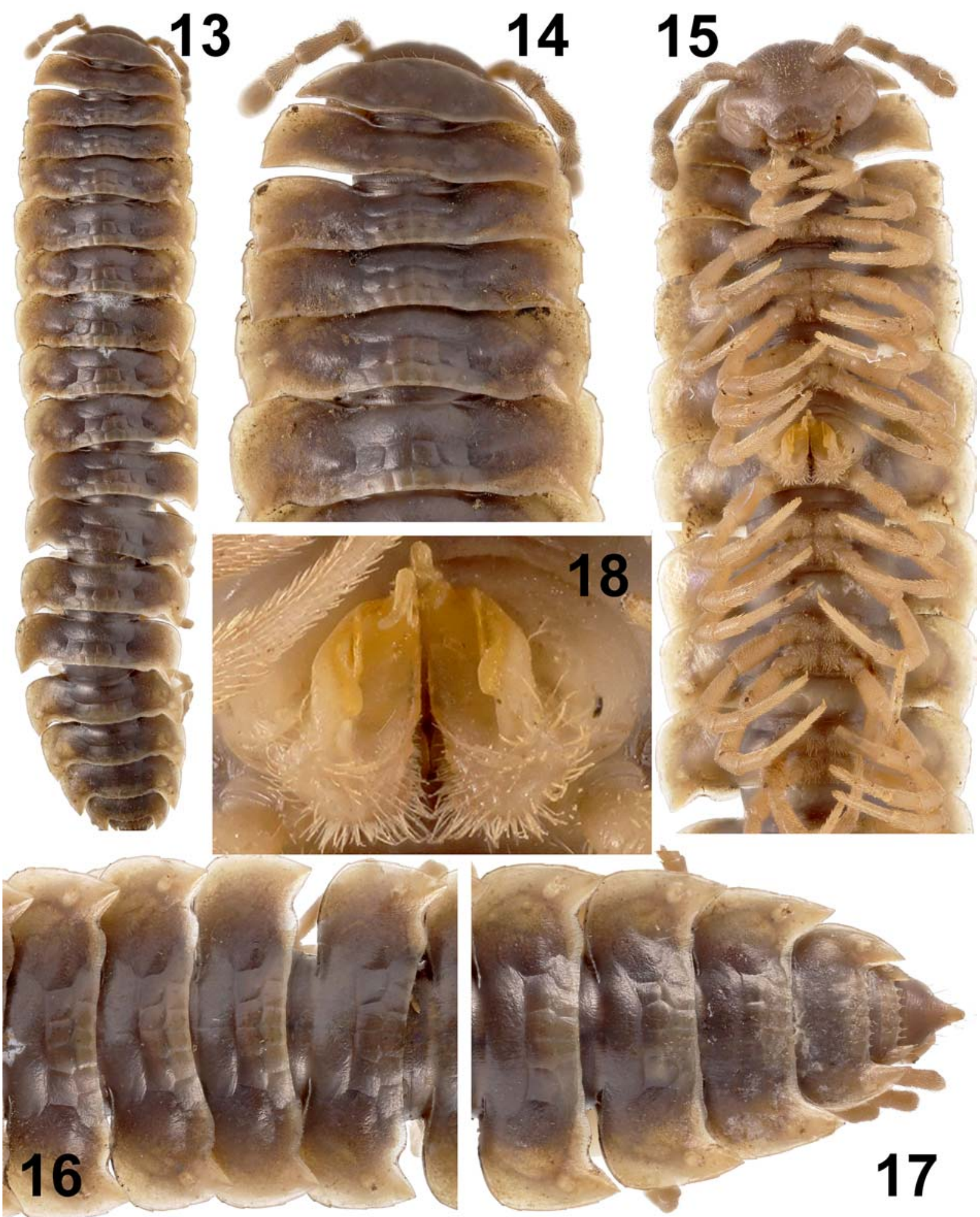

Figs 13-18. Epanerchodus wolongensis sp.n., $0^{7}$ paratype. 13 - habitus, dorsal view; 14, 15 - anterior part of body, dorsal and ventral views, respectively; 16 - midbody segments, dorsal view; 17 - posterior part of body, dorsal view; 18 — gonopods in situ, ventral view. Pictures by K.V. Makarov, taken not to scale.

Рис. 13-18. Epanerchodus wolongensis sp.n., паратип О7. 13 - общий вид, сверху; 14, 15 - передняя часть тела, соответственно сверху и снизу; 16 - среднетуловищные сегменты, сверху; 17 - задняя часть тела, сверху; 18 - гоноподы на месте, снизу. Фотографии К.В. Макарова, снято без масштаба. 


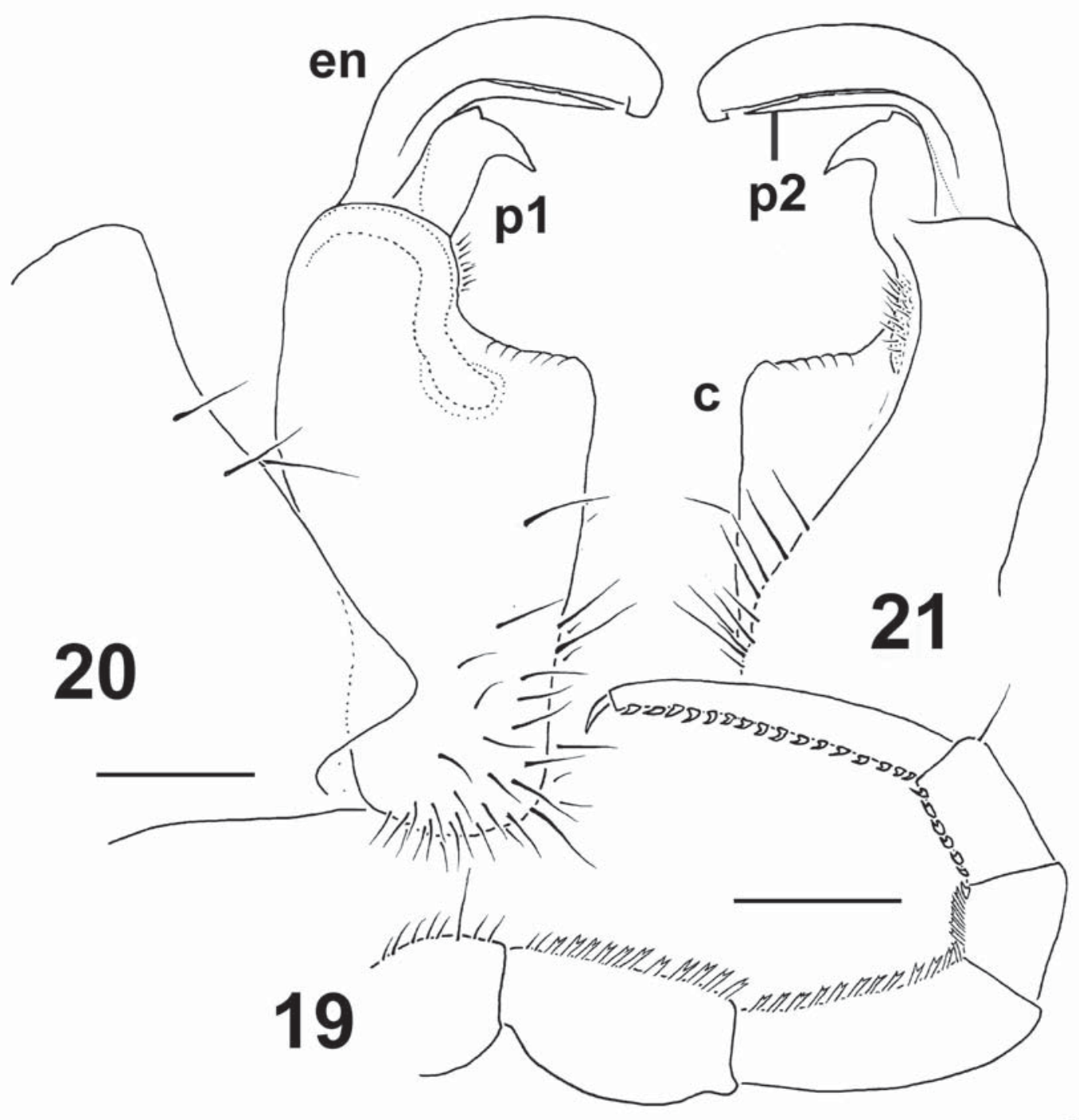

Figs 19-21. Epanerchodus wolongensis sp.n., $\sigma^{7}$ paratype. 19 - leg 9, lateral view; 20, 21 - right gonopod, lateral and mesal views, respectively. Scale bars: $1.0(19)$ and $0.2 \mathrm{~mm}(20,21)$. Designations explained in text.

Pис. 19-21. Epanerchodus wolongensis sp.n., паратип О7. 19 - нога 9, сбоку; 20, 21 - правый гонопод, соответственно сбоку и изнутри. Масштаб: $1,0(19)$ и 0,2 мм $(20,21)$. Объяснения обозначений в тексте.

all setae simple, very poorly branching setae with minute, distal, side branchlets being observed only on slender prefemora, the latter devoid of lateral bulges (Fig. 7).

Gonopods (Figs 3, 6, 8-12) with large, subquadrate coxae (cx) strongly fused medially at base and carrying a few long setae ventrally; a long, simple and unciform cannula (ca) as usual. Telopodite elongated, stout, subfalcate only distally, prefemorite (= densely setose part) about half as long as entire telopodite; seminal groove running mesally over most of its extent, only distally moving frontally to recurve first laterad and then a little basad at base of a somewhat shorter, more complex endomere (en); exomere absent; clivus (c) a large, lateral and irregularly rounded lobe; a round accessory seminal chamber and a hairy pulvillus hidden inside a cavity between $\mathbf{c}$ and mesal wall of telopodite; en strong, regularly curved, slightly thickened in midway part and rounded apically, with a group of four tiny filaments below apex; a rather small, curved (p1) and a longer, straight, spiniform process (p2) at base of en.
REMARKS. Using the latest available keys to Epanerchodus species of mainland China [Golovatch, 2014a; Liu, Golovatch, 2018], as well as the later described congeners [Liu, Huo, 2020], E. liuae sp.n. invariably keys out to deadend couplets. The closest congeners, both morphologically and geographically, seem to be E. yunnanensis Golovatch, 2014, E. fuscus Golovatch, 2015, and E. typicus Golovatch, 2014, incidentally all three from Yunnan [Golovatch, 2014a, b, 2015]. They all share, among many other characters, the head being distinctly narrower than the collum, combined with a poorly developed tergal sculpture; a brown general colouration; $\sigma^{7}$ prefemora non-bulged laterally; a stout gonopodal telopodite lacking an exomere; a relatively short, simple and strong endomere (en) supplied with two processes at the base (p1 and $\mathbf{p} \mathbf{2})$.

However, E. liuae sp.n. differs from E. yunnanensis, the latter species from Dali County, in being somewhat larger (ca $25 \mathrm{~mm}$ long and $4.2 \mathrm{~mm}$ wide, vs. 21-23 mm long and 3.2-3.5 mm wide), o legs devoid of sphaerotrichomes (vs. 

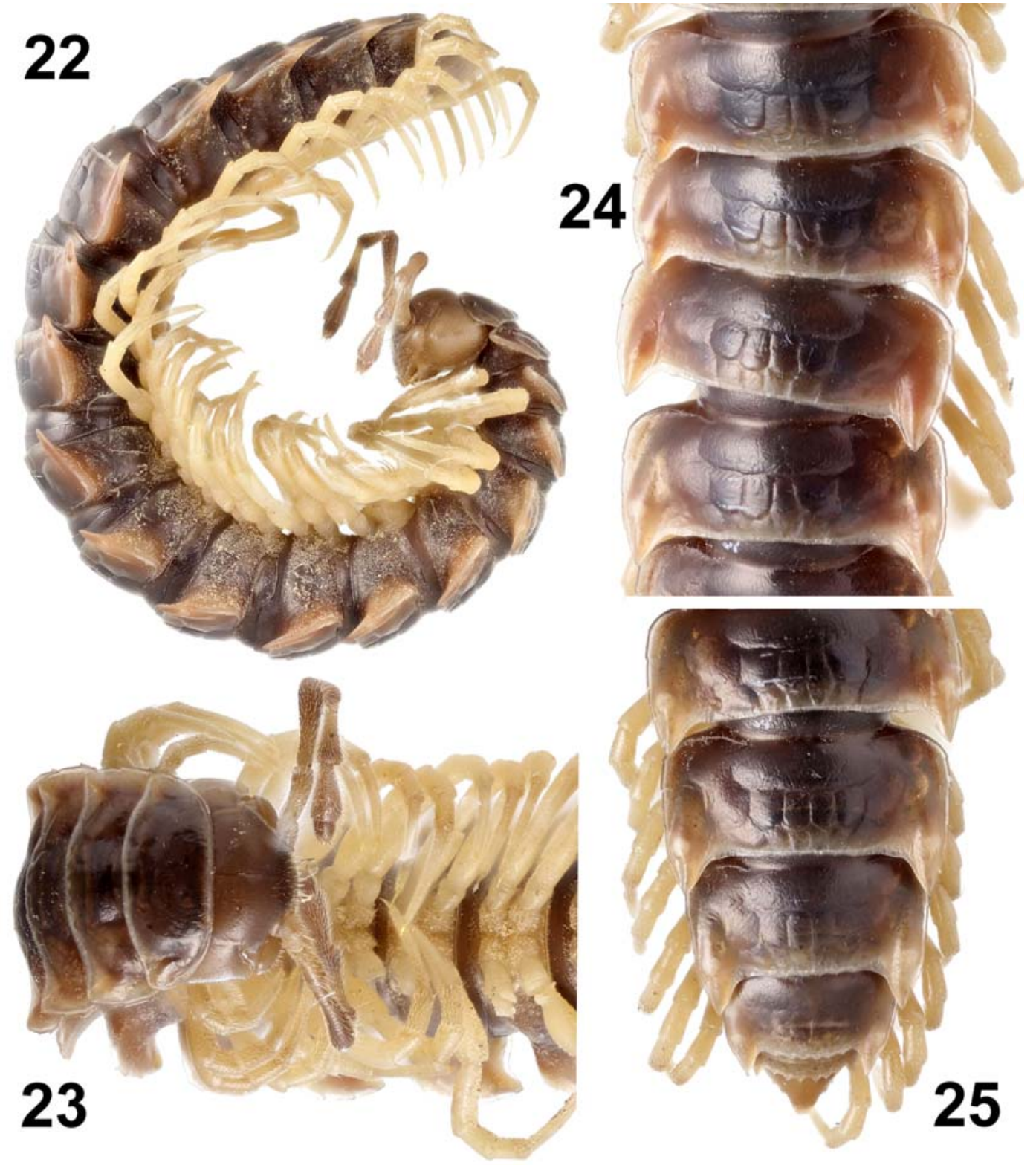

Figs 22-25. Epanerchodus potanini Golovatch, 1991, $0^{7}$ from Qinyugou, Gansu. 22 - habitus, lateral view; 23 - anterior part of body, ventral view; 24 - midbody segments, dorsal view; 25 - posterior part of body, dorsal view. Pictures by K.V. Makarov, taken not to scale.

Рис. 22-25. Epanerchodus potanini Golovatch, 1991, О’ из Qinyugou (Ганьсу). 22 - общий вид, сбоку; 23 - передняя часть тела, снизу; $24-$ среднетуловищные сегменты, сверху; 25 - задняя часть тела, сверху. Фотографии К.В. Макарова, снято без масштаба.

present on $\sigma^{7}$ postfemora, tibiae and tarsi in E. yunnanensis), and the gonopods showing a curved and rounded process p1, and a thicker and apically rounded endomere (en) (vs. a straight and truncate $\mathbf{p} 1$ and a more slender and apically trifid en in E. yunnanensis).

The type localities of both E. liuae sp.n. and E. fuscus lie within Lanping County, quite close to one another. Yet $E$. liuae sp.n. seems to differs from E. fuscus even more strongly: the colouration in E. liuae sp.n. is generally lighter brown (vs. very dark brown in E. fuscus), the size is larger ( $25 \mathrm{~mm}$ long and $4.2 \mathrm{~mm}$ wide in E. liuae sp.n., vs. $17 \mathrm{~mm}$ long and $4.0 \mathrm{~mm}$ wide in E. fuscus), $\sigma^{\top}$ legs are devoid of sphaerotri- chomes (vs. in addition to modified bi- or trifid setae on $\sigma^{7}$ prefemora and femora, present on $\sigma^{7}$ postfemora, tibiae and tarsi in E. fuscus), and the gonopods showing a curved and rounded process $\mathbf{p 1}$, and a thicker and apically rounded endomere (en) (vs. a short, strong and lobe-shaped p1, and a shorter, only slightly curved and apically subtruncate en in E. fuscus).

Epanerchodus liuae sp.n. differs from E. typicus, the latter species from Shangrila County, in being somewhat larger (25 mm long and $4.2 \mathrm{~mm}$ wide in E. liuae sp.n., vs. 19 $\mathrm{mm}$ long and $3.8 \mathrm{~mm}$ wide in E. typicus), lighter brown ( $v s$. dark brown in E. typicus), $O^{\top}$ legs are devoid of sphaerotri- 

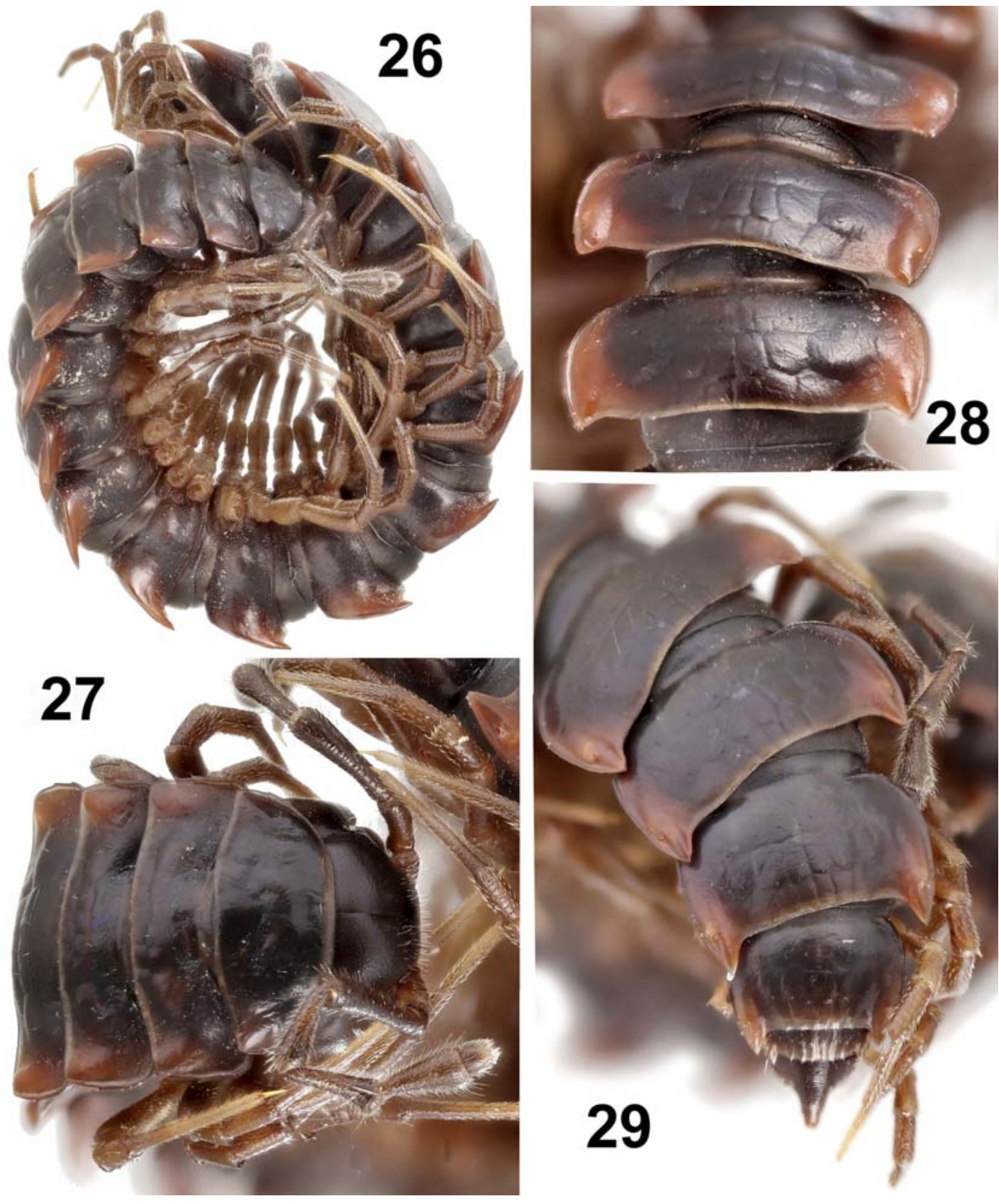

Figs 26-29. Epanerchodus potanini Golovatch, 1991, O7 from near Kekecun, Sichuan. 26 - habitus, lateral view; 27 - anterior part of body, dorsal view; 28 - midbody segments, dorsal view; 29 - posterior part of body, dorsal view. Pictures by K.V. Makarov, taken not to scale.

Рис. 26-29. Epanerchodus potanini Golovatch, 1991, о7 из окрестностей Кekecun (Сычуань). 26 - общий вид, сбоку; 27 передняя часть тела, сверху; 28 - среднетуловищные сегменты, сверху; 29 - задняя часть тела, сверху. Фотографии К.В. Макарова, снято без масштаба.

chomes ( $v s$. in addition to clearly modified bi- or trifid setae on $\sigma^{7}$ prefemora and femora, present on $\sigma^{7}$ postfemora, tibiae and tarsi in E. typicus), and the gonopods showing a curved and bifid process $\mathbf{p 1}$, and a thicker and apically rounded endomere (en) with subapical filaments (vs. a short, strong and lobe-shaped p1, and an apically subacuminate and subunciform en devoid of subapical filaments in $E$. typicus).

\section{Epanerchodus wolongensis sp.n.}

Figs 13-21.

HOLOTYPE O (SMF), China, Sichuan Prov., Wolong Town, $\mathrm{N} 31^{\circ} 01^{\prime}$, E $103^{\circ} 10^{\prime}, 1900 \mathrm{~m}$ a.s.l., 28.IV.2012, J. Martens leg.

PARATYPES: $1 \sigma^{\top}, 2$ 우, 2 fragments (SMF), $10^{\top}$ (ZMUM), same data, together with holotype.

NAME. To emphasize Wolong, the type locality; adjective. 


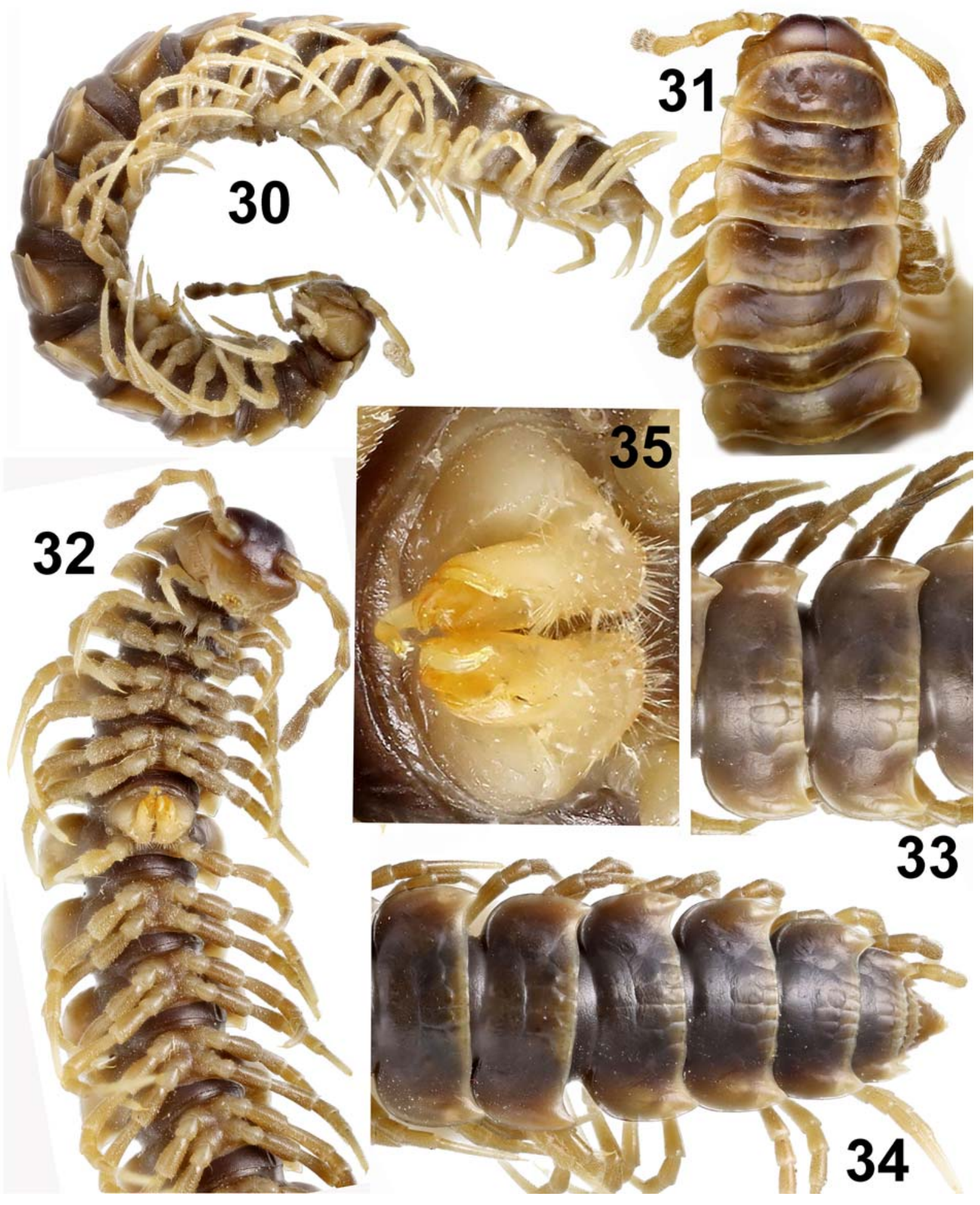

Figs 30-35. Epanerchodus potanini Golovatch, 1991, ơ from Maanyao-Yeniutang Pass, Sichuan. 30 - habitus, lateral view; 31, 32 anterior part of body, dorsal and ventral views, respectively; 33 - midbody segments, dorsal view; 34 - posterior part of body, dorsal view; 35 - both gonopods in situ, ventral view. Pictures by K.V. Makarov, taken not to scale.

Рис. 30-35. Epanerchodus potanini Golovatch, 1991, О7 с перевала Maanyao-Yeniutang (Сычуань). 30 - общий вид, сбоку; 31, 32 - передняя часть тела, соответственно сверху и снизу; 33 - среднетуловищные сегменты, сверху; 34 - задняя часть тела, сверху; 35 - оба гонопода на месте, снизу. Фотографии К.В. Макарова, снято без масштаба. 


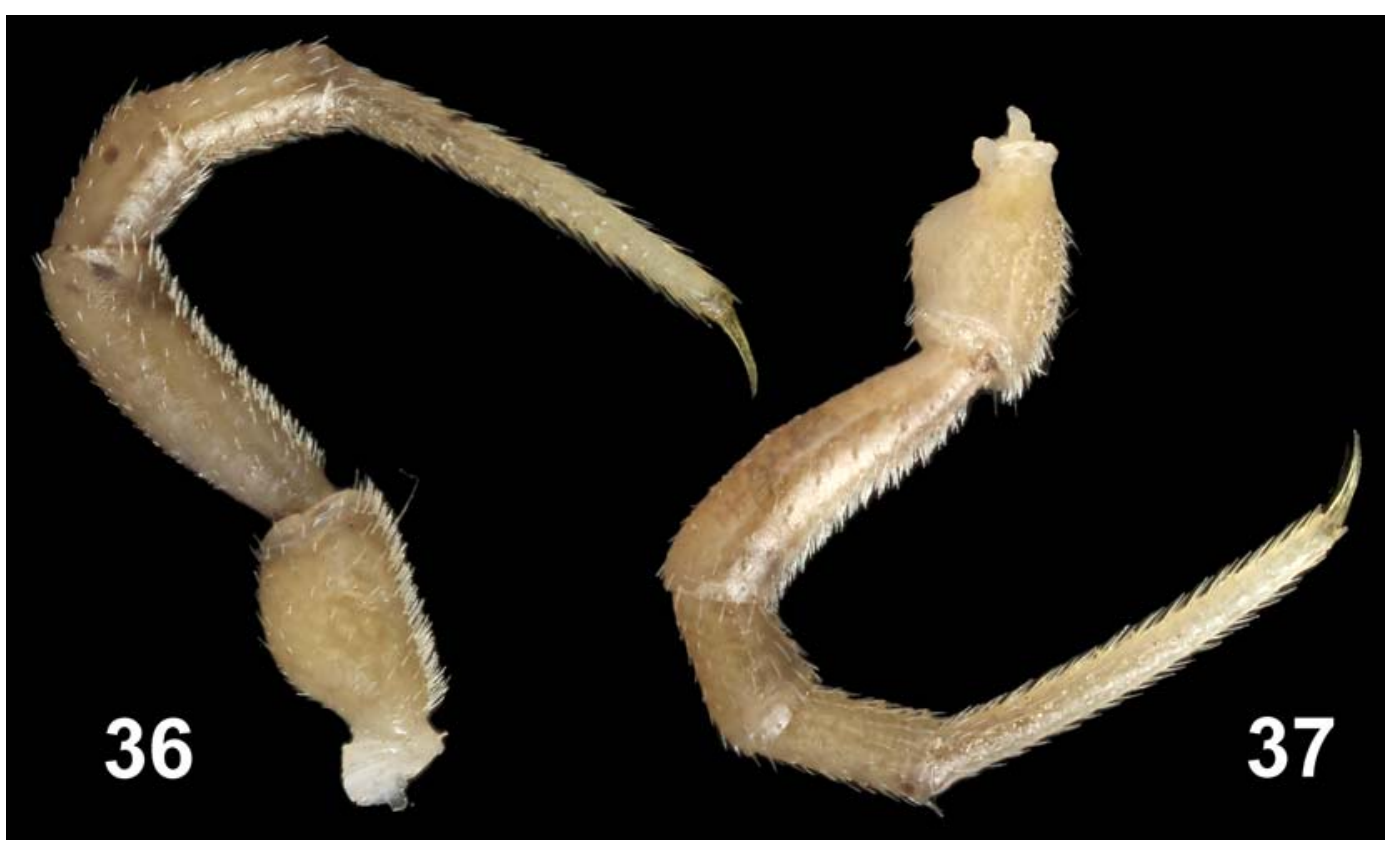

Figs 36, 37. Epanerchodus potanini Golovatch, 1991, ơ from Ershili, Sichuan. 36 - leg 9, lateral view; 37 - leg 7, lateral view. Pictures by K.V. Makarov, taken not to scale.

Рис. 36, 37. Epanerchodus potanini Golovatch, 1991, о7 из Ershili (Сычуань). 36 - нога 9, сбоку; 37 - нога 7, сбоку. Фотографии К.В. Макарова, снято без масштаба.

DIAGNOSIS. In sharing, among numerous other characters, the head distinctly narrower than the collum, combined with a poorly developed tergal sculpture; a brown general colouration; a stout gonopodal telopodite lacking an exomere; a relatively short, simple and strong endomere (en) supplied with two processes at its base (p1 and p2), $E$. wolongensis sp.n. seems to be especially similar to E. liuae sp.n. (see above) and E. yunnanensis (see Golovatch, 2014a]. However, it differs readily from both by the ventral setation of $\sigma^{7}$ legs, the presence of laterally bulging $\sigma^{7}$ femora, and the peculiar shapes of the clivus, endomere and process $\mathbf{p} \mathbf{1}$ of the gonopods.

DESCRIPTION. Length of $\sigma^{7} \sigma^{7}$ ca $15 \mathrm{~mm}$, width of midbody pro- and metazonae 1.1 and $2.0 \mathrm{~mm}$, respectively. Length of 우 ca 16 or $20 \mathrm{~mm}$, width of midbody pro- and metazonae $1.5-1.6$ and $2.5-2.6 \mathrm{~mm}$, respectively. Colouration in alcohol mostly rather uniformly light grey pinkish, more rarely brown with lighter paraterga and legs (Figs 13-17).

All characters as in E. liuae sp.n., except as follows.

Tegument shining. Antennae slightly shorter, and paraterga slightly less strongly developed and set lower, in + than in $\sigma^{7}$. In width, head $<$ collum $<$ segment $2<3=4<$ $5=15(16)$, thereafter body gradually tapering towards telson (Fig. 13). Paraterga very strongly developed, mostly weakly upturned above dorsum. Metatergal sculpture typical, but usually slightly more strongly developed (Figs 13-17).

Legs generally rather long and slender, incrassate and slightly longer in $\sigma^{7}$ compared to $q$ (Figs 15, 19), very densely setose, ventrally with bi- or trifid setae on prefemo$\mathrm{ra}$, femora and most of postfemora, and with sphaerotrichomes on postfemora (only distally), tibiae and tarsi in $\sigma^{7}$, only with simple setae in $\circ$; prefemora clearly bulged laterad only in $\sigma^{7}$ (Fig. 19).

Gonopods (Figs 18, 20,21) with prefemorite (= densely setose part) about $1 / 3$ as long as entire telopodite; clivus (c) a large, lateral, subrectangular lobe; endomere (en) very strong and regularly curved, at apex narrowly subtruncate and subunciform, devoid of subapical filaments; a strong axe-shaped (p1) and a longer spiniform process (p2) at base of en.

REMARK. Using the latest available keys to Epanerchodus species of mainland China [Golovatch, 2014a; Liu, Golovatch, 2018], as well as the later described congeners [Liu, Huo, 2020] and the above E. liuae sp.n., like the latter species, E. wolongensis sp.n. invariably keys out to deadend couplets.

\section{Epanerchodus martensi Golovatch, 2014}

MATERIAL. $1 \sigma^{\top}, 1$, 7 juv. (SMF), China, Shaanxi Prov., Taibai Shan Mts, S flanks, above Houshenzi, $1700 \mathrm{~m}$ a.s.l., primary broadleaved forest, 20.VII.1997, P. Jäger \& J. Martens leg.

REMARK. The above samples represent strict topotypes of this species [Golovatch, 2014a].

\section{Epanerchodus potanini Golovatch, 1991} Figs 22-45.

MATERIAL. $2 O^{7} \sigma^{7}$ (ZMUM), China, Gansu Prov., NNE of Zhugqu, Minjiang Basin, $3 \mathrm{~km}$ ENE of Xiaohuangya, Qinyugou, N $33^{\circ} 50^{\prime} 08^{\prime \prime}$, E $104^{\circ} 25^{\prime} 39^{\prime \prime}, 3045 \mathrm{~m}$ a.s.1., 4.VII.2017, I. Belousov \& I. Kabak leg.; $10^{7}, 1$, 1 subadult (ZMUM), China, Sichuan Prov.,

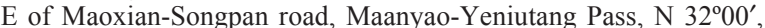
E 103'45'24", $3955 \mathrm{~m}$ a.s.1., 7.VII.2015; 1 ○', 2 우 (ZMUM), China, Sichuan Prov., W of Maoxian, $8.3 \mathrm{~km}$ NW of Kekecun, N $31^{\circ} 41^{\prime} 44^{\prime \prime}$, E $103^{\circ} 44^{\prime} 02^{\prime \prime}, 2630 \mathrm{~m}$ a.s.1., 7.VII.2015; $1 \mathrm{O}^{\top}, 1$, 2 subadults (ZMUM), China, Sichuan Prov., N of Wenchuan, NE of

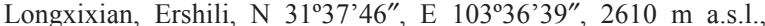
8.VII.2015; $1 \mathrm{O}^{7}$ (ZMUM), China, Sichuan Prov., $\mathrm{N}$ of Wenchuan, NE of Longxixian, $2.4 \mathrm{~km}$ NNE of Ershili, N 31 $38^{\circ} 54^{\prime \prime}$, E $103^{\circ} 37^{\prime} 29^{\prime \prime}, 3140$ m a.s.1., 9.VII.2015, all I. Belousov, I. Kabak \& G. Davidian leg. 


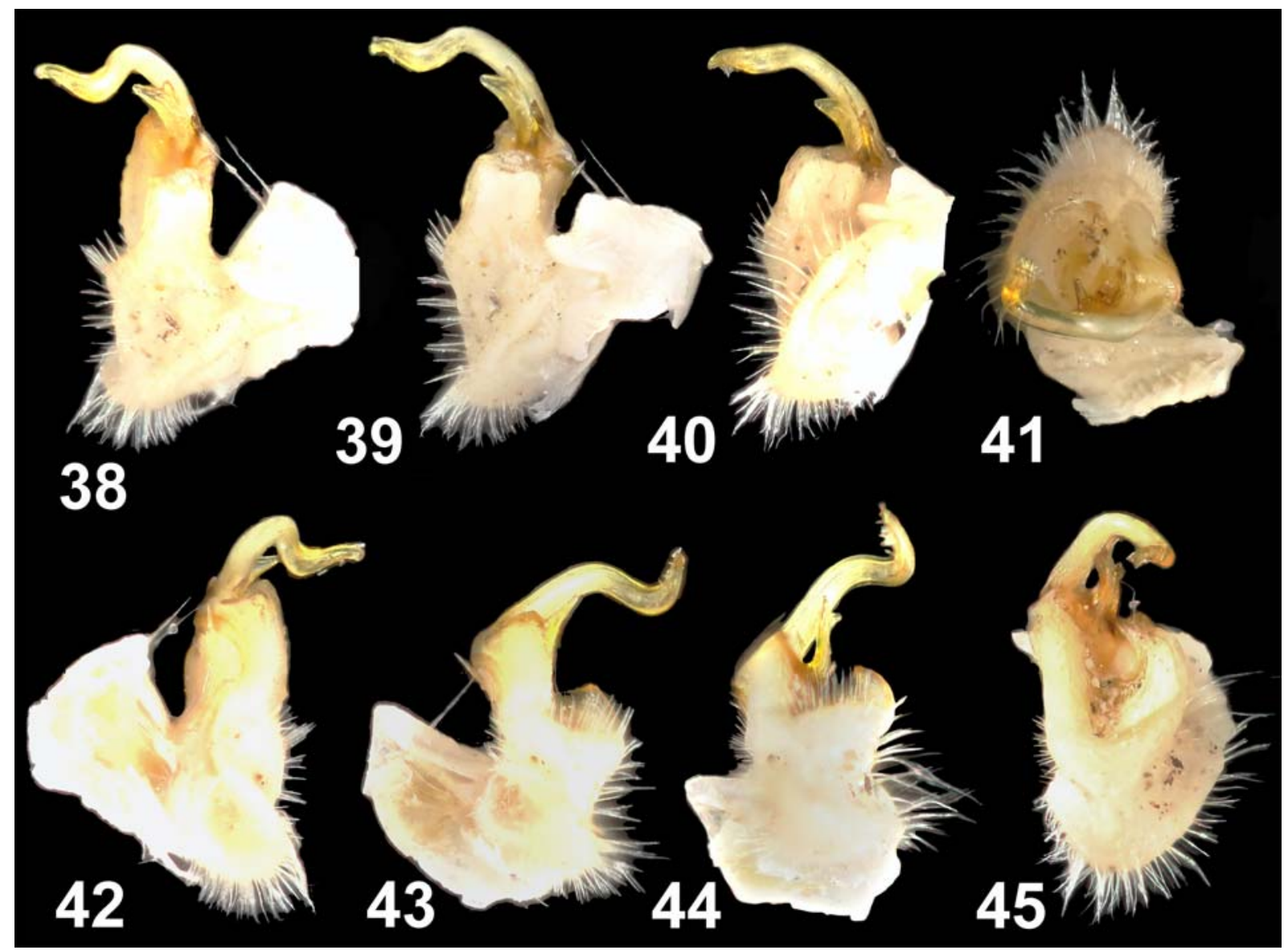

Figs 38-45. Epanerchodus potanini Golovatch, 1991, $0^{7}$ from Ershili, Sichuan. Right gonopod, various views. Pictures by K.V. Makarov, taken not to scale.

Рис. 38-45. Epanerchodus potanini Golovatch, 1991, О’ из Ershili (Сычуань). Правый гонопод, разные аспекты. Фотографии К.В. Макарова, снято без масштаба.

REMARKS. This common species is widespread in the mountains of Gansu and Sichuan provinces, marginally occurring in northwestern Yunnan as well [Golovatch, 1991, $2014 a$, b]. It seems to be typically high-montane, encountered between 2475 and $4035 \mathrm{~m}$ a.s.l. New illustrations are provided to document variations in habitus and colouration (Figs 22-35), as well as leg (Figs 36, 37) and gonopodal structure (Figs 38-45).

Acknowledgements. Special thanks are due to the collectors who rendered me their material for treatment: Igor Belousov, Ilya Kabak and Genrikh Davidian (all St. Peterburg, Russia), as well as Jochen Martens (Mainz, Germany) and Peter Jäger (SMF, Germany). Kirill V. Makarov (Moscow, Russia) very skillfully took and edited the colour pictures used in the present study. The author was partly supported by the Presidium of the Russian Academy of Sciences, Programme No. 41 "Biodiversity of Natural Systems and Biological Resources of Russia".

\section{References}

Golovatch S.I. 1991. The millipede family Polydesmidae in Southeast Asia, with notes on phylogeny (Diplopoda: Polydesmida) // Steenstrupia. Vol.17. No.4. P.141-159.
Golovatch S.I. 2014a. Review of the millipede genus Epanerchodus Attems, 1901 in continental China, with descriptions of new species (Diplopoda: Polydesmidae) // Zootaxa. Vol.3760. No.2. P.275-288

Golovatch S.I. 2014b. Two new and one little-known species of the millipede genus Epanerchodus Attems, 1901 from southern China (Diplopoda, Polydesmida, Polydesmidae) // Fragmenta Faunistica. Vol.56 (for 2013). No.2. P.157-166.

Golovatch S.I. 2015. Two new species of the millipede order Polydesmida from southern China (Diplopoda) // Zoologicheskii zhurnal. Vol.64. No.9. P.1023-1028.

Golovatch S.I., Liu W.X. 2020. Diversity, distribution patterns, and fauno-genesis of the millipedes (Diplopoda) of mainland China // ZooKeys. Vol.930. P.153-198.

Liu W.X., Golovatch S.I. 2018. The millipede genus Epanerchodus Attems, 1901 in continental China, with descriptions of seven new cavernicolous species (Diplopoda, Polydesmida, Polydesmidae) // Zootaxa. Vol.4459. No.1. P.53-84.

Liu W.X., Huo Q.B. 2020. Two new species and a new record of polydesmoid millipedes from Jiangsu and Zhejiang provinces, eastern China (Diplopoda, Polydesmida) // Zootaxa. Vol.4722. No.1. P.41-49. 